\title{
Preliminary researches on conditions to extract alchol soluble proteins of leaves of Wedelia trilobata (L.) Hitchc.
}

\author{
Liguo Qiu, Gan Zhao*, and Tuanna Li \\ College of Life Sciences, South China Agricultural University, Guangzhou 510642, China
}

\begin{abstract}
The conditions to extract alchol soluble proteins of leaves of Wedelia trilobata (L.) Hitchc. were discussed. When the extractant was alcohol, the weight of leave(g) -to- volume of $75 \%$ alcohol solution $(\mathrm{mL})$ ratio was $1: 10$, temperature for extraction was $50^{\circ} \mathrm{Cand}$ the extraction period was $2 \mathrm{hrs}$, the concentration of alcohol solution needed for the best extraction effect was $95 \%(\mathrm{~V} / \mathrm{V})$. When the extractant was $75 \%$ alcohol solution, the temperature for extraction was $50^{\circ} \mathrm{Cand}$ the extraction period was $2 \mathrm{hrs}$, the weight of leave $(\mathrm{g})$-to- volume of $75 \%$ alcohol solution $(\mathrm{mL})$ ratio needed for the best extraction effect was $1: 20$. When the extractant was $75 \%$ alcohol solution, the weight of leave $(\mathrm{g})$-to- volume of $75 \%$ alcohol solution $(\mathrm{mL})$ ratio was $1: 10$ and the extraction period was $2 \mathrm{hrs}$, the temperature needed for the best extraction effect was $55^{\circ} \mathrm{C}$. When the extractant was $75 \%$ alcohol solution, the weight of leave(g) -tovolume of $75 \%$ alcohol solution $(\mathrm{mL})$ ratio was $1: 10$ and the temperature for extraction was $50^{\circ} \mathrm{C}$, the extraction period needed for the best extraction effect was $2 \mathrm{hrs}$.
\end{abstract}

\section{Introduction}

Alcohol soluble proteins have been studied in common wheat [1], onion [2], corn [3], soybean [4], Pinus tabulaeformis [5], sorghum [6], rice [7], proso millet [8], Sudan grass [9], Ganoderma lucidum [10], coconut [11], Zanthoxylum armatum [12], Moso bamboo [13], white kidney bean [14], beer grains [15] and in Roegneria , Elymus, Hystrix and Kengyilia [16]. Xu et al [17] studied moisture-resistance and antioxidation of alchol soluble proteins for application in food preservation. He et al [18] showed that zein could be used to preserve green peppers, tomatoes, sausages and salted meat fresh. The mice fed the proso millet prolamin (supplemented with $1.82 \%$ Lys and $0.23 \%$ Trp) showed a higher HDL-c content and a lower atherogenic index [8]. Alcohol soluble proteins have been paid attention to in pharmaceutics [19] and as carriers to load nutrients [20]. As one of alien invasive plants, the comprehensive utilization of Wedelia trilobata (L.) Hitchc has been attractive [21]. Here a try was done on the conditions to extract alcohol soluble proteins from leaves of it.

\section{Material, reagents and instruments}

Leaves of Wedelia trilobata (L.) Hitchc were collected on campus in South China Agricultural University. Analytical reagents suah as alcohol was made in China. 752 Type -Ultraviolet Grating Spectrophotometer was made by Shanghai Accurate Scientific Instruments Corporation. HWS24 Type Electro-thermal Constant
Temperature Water Bath was made by Shanghai Yiheng Technology Corporation. HF-200Type Electronic Balance was made by A\&D Company, limited. 5810(R) High-speed Refrigerated Centrifuge was made by Eppendorf Ltd.

\section{Experimental methods}

\subsection{The method to extract alchol soluable proteins from leaves of Wedelia trilobata (L.) Hitchc}

$2.0 \mathrm{~g}$ leaves of Wedelia trilobata (L.) Hitchc were mixed with $20 \mathrm{~mL}$ extractant and a littlt of quartz sand, and were ground. And after being dealt with at $50^{\circ} \mathrm{C}$ for $2 \mathrm{hrs}$, the mixture above was centrifugated at $10000 \mathrm{rpm}$ for 10 minutes. The supernatant was collected for determination.

\subsection{The influences of alcohol on the effects to extract alcohol soluble proteins from leaves of Wedelia trilobata (L.) Hitchc at different concentrations}

The experiments were done basicaly according to the method 3.1, but the alcohol concentration was used as $60 \%, 75 \%$ and $95 \%$ respectively, according to the volume of alcohol -to- volume of alcohol mixed with DDW ratio.

\footnotetext{
*Corresponding author is Gan Zhao whose E-mail is zg200010@163.com.
} 


\subsection{The influences of $75 \%$ alcohol solution on the effects to extract alcohol soluble proteins from leaves of Wedelia trilobata (L.) Hitchc with different leaf-to-solution ratios}

The experiments were done basicaly according to the method 3.1, but the leaf-to-solution ratio used was changed as 1:5,1:10,1:15 and 1:20 respectively, according to the weight of leave(g) -to- volume of $75 \%$ alcohol solution $(\mathrm{mL})$ ratio.

3.4 The influences of $75 \%$ alcohol solution on the effects to extract alcohol soluble proteins from leaves of Wedelia trilobata (L.) Hitchc at different temperatures

The experiments were done basicaly according to the method 3.1, but only the $75 \%$ alcohol solution was used at $35^{\circ} \mathrm{C}, 42^{\circ} \mathrm{C}, 45^{\circ} \mathrm{C}, 50{ }^{\circ} \mathrm{C}$ and $55^{\circ} \mathrm{C}$ respectively.

3.5 The influences of $75 \%$ alcohol solution on the effects to extract alcohol soluble proteins from leaves of Wedelia trilobata (L.) Hitchc for different extraction periods

The experiments were done basicaly according to the method 3.1, but only the $75 \%$ alcohol solution was used for 30mins, 60 mins, 90 mins and 120 mins respectively.

\subsection{Measurement of protein content}

The experiments were done basicaly according to the Bradford's method [22]. When measuring the protein content of the extracts, the extractants used were used as contrasts in stead of DDW.

\section{Results and Discussion}

\subsection{The influences of alcohol on the effects to extract alcohol soluble proteins from leaves of Wedelia trilobata (L.) Hitchc at different concentrations}

According to Table 1, when extracting alcohol soluble proteins using different alcohol solution from leaves of Wedelia trilobata (L.) Hitchc ,the extraction effect by $95 \%$ alcohol solution was the best, and the one by $75 \%$ alcohol was the second. The one by $60 \%$ alcohol was the lowest.

Table 1: The influences of alcohol on the effects to extract alcohol soluble proteins from leaves of Wedelia trilobata (L.) Hitchc at different concentrations

\begin{tabular}{|c|c|c|c|c|}
\hline Serial number & $\begin{array}{c}\text { Weight of leaves of Wedelia } \\
\text { trilobata (L.) Hitchc }(\mathrm{g})\end{array}$ & $\begin{array}{c}\text { Concentration of } \\
\text { alcohol }(\mathrm{V} / \mathrm{V})\end{array}$ & $\begin{array}{c}\text { Usage of the } \\
\text { extractant }(\mathrm{mL})\end{array}$ & $\begin{array}{c}\text { alcohol soluble proteins } \\
\text { content }(\mu \mathrm{g} / \mathrm{mL})(\mathrm{S} . \mathrm{E} .)\end{array}$ \\
\hline 1 & 2 & $60 \%$ & 20 & $244.2442 \pm 6.364285$ \\
\hline 2 & 2 & $75 \%$ & 20 & $333.4728 \pm 3.543484$ \\
\hline 3 & 2 & $95 \%$ & 20 & $506.0142 \pm 4.055204$ \\
\hline
\end{tabular}

\subsection{The influences of $75 \%$ alcohol solution on the effects to extract alcohol soluble proteins from leaves of Wedelia trilobata (L.) Hitchc with different leaf-to- solution ratios}

According to Table 2, when extracting alcohol soluble proteins using $75 \%$ alcohol solution from leaves of
Wedelia trilobata (L.) Hitchc, the different ratio between the weight of leave $(\mathrm{g})$ and the volume of $75 \%$ alcohol solution $(\mathrm{mL})$ could influence the extraction effects. When the ratio was $1(\mathrm{~g}): 20(\mathrm{~mL})$, the extraction effect was the best. And when the ratio became $1(\mathrm{~g}): 5$ $(\mathrm{mL}), 1(\mathrm{~g}): 10(\mathrm{~mL})$ and $1(\mathrm{~g}): 15(\mathrm{~mL})$ respectively, the extraction effects declined respectively.

Table 2: The influences of $75 \%$ alcohol solution on the effects to extract alcohol soluble proteins from leaves of Wedelia trilobata (L.) Hitche with different leaf-to-solution ratios

\begin{tabular}{|c|c|c|c|c|}
\hline Serial number & $\begin{array}{c}\text { Weight of leaves of } \\
\text { Wedelia trilobata }(L .) \\
\text { Hitchc }(\mathrm{g})\end{array}$ & $\begin{array}{c}\text { Weight of leave(g) -to- } \\
\text { volume of } 75 \% \text { alcohol } \\
\text { solution }(\mathrm{mL}) \text { ratio }\end{array}$ & $\begin{array}{c}\text { Usage of the } \\
\text { extractant }(\mathrm{mL})\end{array}$ & $\begin{array}{c}\text { alcohol soluble proteins } \\
\text { content }(\mu \mathrm{g} / \mathrm{mL})(\mathrm{S} . \mathrm{E} .)\end{array}$ \\
\hline 1 & 2 & $1: 5$ & 10 & $110.1549 \pm 4.589352$ \\
\hline 2 & 2 & $1: 10$ & 20 & $343.3323 \pm 3.807949$ \\
\hline 3 & 2 & $1: 15$ & 30 & $292.0628 \pm 4.580517$ \\
\hline 4 & 2 & $1: 20$ & 40 & $238.8215 \pm 2.186204$ \\
\hline
\end{tabular}

4.3 The influences of $75 \%$ alcohol solution on the effects to extract alcohol soluble proteins from leaves of Wedelia trilobata (L.) Hitchc at different temperatures extraction effects of alcohol soluble proteins from leaves of Wedelia trilobata (L.) Hitchc using 75\% alcohol solution. When temperatures changed from $35^{\circ} \mathrm{C}, 42^{\circ} \mathrm{C}$, $45^{\circ} \mathrm{C}, 50^{\circ} \mathrm{C}$ to $55^{\circ} \mathrm{C}$, the extraction effects gradually rised, and the best effect could be get at $55^{\circ} \mathrm{C}$.

According to Table 3, temperatures could influence the 


\subsection{The influences of $75 \%$ alcohol solution on the effects to extract alcohol soluble proteins from leaves of Wedelia trilobata (L.) Hitchc for different extraction periods}

According to Table 4, extraction periods could influence the extraction effects of alcohol soluble proteins from leaves of Wedelia trilobata (L.) Hitchc using 75\% alcohol solution. When extraction periods changed from 30mins, $60 \mathrm{mins}$, 90mins to $120 \mathrm{mins}$, the extraction effects gradually rised, and the best effect could be get when leaves of Wedelia trilobata (L.) Hitchc were treated by $75 \%$ alcohol solution for 120 mins.

Table 3: The influences of $75 \%$ alcohol solution on the effects to extract alcohol soluble proteins from leaves of Wedelia trilobata (L.) Hitchc at different temperatures

\begin{tabular}{|c|c|c|c|c|}
\hline $\begin{array}{c}\text { Serial } \\
\text { number }\end{array}$ & $\begin{array}{c}\text { Weight of leaves of Wedelia } \\
\text { trilobata (L.) Hitchc }(\mathrm{g})\end{array}$ & Temperature $\left({ }^{\circ} \mathrm{C}\right)$ & $\begin{array}{c}\text { Usage of the } \\
\text { extractant }(\mathrm{mL})\end{array}$ & $\begin{array}{c}\text { alcohol soluble proteins } \\
\text { content }(\mu \mathrm{g} / \mathrm{mL})(\mathrm{S} . \mathrm{E} .)\end{array}$ \\
\hline 1 & 2 & 35 & 20 & $235.3707 \pm 3.509025$ \\
\hline 2 & 2 & 42 & 20 & $273.3298 \pm 3.543484$ \\
\hline 3 & 2 & 45 & 20 & $341.8533 \pm 3.11785$ \\
\hline 4 & 2 & 50 & 20 & $343.3323 \pm 8.302893$ \\
\hline 5 & 2 & 55 & 20 & $457.2096 \pm 2.608581$ \\
\hline
\end{tabular}

Table 4: The influences of $75 \%$ alcohol solution on the effects to extract alcohol soluble proteins from leaves of Wedelia trilobata (L.) Hitchc for different extraction periods

\begin{tabular}{|c|c|c|c|c|}
\hline Serial number & $\begin{array}{c}\text { Weight of leaves of Wedelia } \\
\text { trilobata (L.) Hitchc }(\mathrm{g})\end{array}$ & $\begin{array}{c}\text { extraction period } \\
(\mathrm{min})\end{array}$ & $\begin{array}{c}\text { Usage of the } \\
\text { extractant }(\mathrm{mL})\end{array}$ & $\begin{array}{c}\text { alcohol soluble proteins } \\
\text { content }(\mu \mathrm{g} / \mathrm{mL})(\mathrm{S} . \mathrm{E} .)\end{array}$ \\
\hline 1 & 2 & 30 & 20 & $79.59042 \pm 2.415077$ \\
\hline 2 & 2 & 60 & 20 & $228.962 \pm 3.257619$ \\
\hline 3 & 2 & 90 & 20 & $334.4587 \pm 5.77013$ \\
\hline 4 & 2 & 120 & 20 & $340.8674 \pm 3.644908$ \\
\hline
\end{tabular}

\section{Discussion}

Liu et al [23 ] got new process of preparing zein with the optimum extraction conditions including ratio of liquid to solid $14: 1(\mathrm{ml} / \mathrm{g})$, temperature $50^{\circ} \mathrm{C}, \mathrm{pH} 9.0$ and time $2 \mathrm{hr}$. Ao et al [10] got the the optimal conditions to extract alcohol soluble proteins from Gnaoderma lucidum, with concentration of ethanol $60 \%, \mathrm{pH} 2.5$, material-liquid ratio 1:40 and extration temperature $60{ }^{\circ} \mathrm{C}$. Ma et al [24] studied the the optimal conditions to extract alcohol soluble proteins from corn gluten meal, showing that liquid-solid ratio and time of microwave-treating could have a greater impact on extraction of the zein than microwave power and particle size. And the optimal conditions including that concentration of ethanol was $80 \%$, one-time extract, liquid-solid ratio was 14: 1, particle size was 20 , microwave power was $420 \mathrm{~W}$, extraction times was 8 and the total time was $360 \mathrm{~s}$. Wang et al [25] showed that the best conditions to extract alcohol soluble proteins from gluten included $70 \%$ of ethanol concentration , solid-liquid ratio of $1: 4$, extraction temperature of $50{ }^{\circ} \mathrm{C}$, $\mathrm{pH}$ of 5.0 and soaking time of 6 hours. $\mathrm{Xu}$ et al [26] showed that the best conditions to extract alcohol soluble proteins from goose millet included ethanol concentration 65\%, solid/liquid (goose millet/ ethanol solution) ratio $1: 6$, temperature $75^{\circ} \mathrm{C}$ and time $1 \mathrm{~h}$. Feng et al [14] got the the best conditions to extract alcohol soluble proteins from (Phaseolus vulgaris L.), showing that the highest extraction effect was obtained when ethanol concentration, solid-liquid ratio, extraction temperature and extraction time were $70 \%, 1: 10,30^{\circ} \mathrm{C}$ and $3.0 \mathrm{~h}$, respectively. Jiang et al [15] showed that the best conditions to extract alcohol soluble proteins from beer grains included $81 \%$ of ethanol concentration, solid-liquid ratio of 1:21 $(\mathrm{g} / \mathrm{mL})$, extraction temperature of $48{ }^{\circ} \mathrm{C}$ and oscillation time of $50 \mathrm{~min}$. Otherwise, Li et al [5] found that the complex reagent consisting of 2-mercaptoethanol $(1 \%)$ and urea $(12 \%)$ was the best for extracting prolamins from $P$. tabulaeformis seeds for acidic polyacrylamide gel electrophoresis (A-PAGE).Wang et al [6] found that $60 \% \tau$-butanol plus $4 \%$ DTT at a sample-weight to extraction-solution ratio of 1:8 $(\mathrm{g}: \mathrm{mL})$ was optimum for kafirin extraction for SDS-PAGE. Deng et al [27] found that $70 \%$ propylalcohol supplemented with $0.2 \%$ DTT was the best extraction solution and the ratio of sample-weight to extraction-solution 1:8 ( $\mathrm{g} / \mathrm{m} \mathrm{L})$ could give optimal results to extract alcohol soluble proteins from seeds of Sorghum sudanense for SDS-PAGE.

It is obvious that different extraction conditions are fit for different materials for different researches. For its low prices and innocuity, maybe ethanol will be an important extractant to extract alcohol soluble proteins in the future. For the special applications of alcohol soluble proteins, the conditions to extract them will be studied further.

\section{References}

1. C.H.Dong, R.H.Xu, Q.Q. Zhang, Journal of Mountain Agriculture and Biology. 22(2), 164-168 (2003)

2. Y.P.Zhang, H.H.Liu, D.W.Ma, S.Z.Gao, Seed.(2), 16, 
$20(2003)$

3. Z.G.Liu, L.L.Hu, X.Shi, Journal of Wuhan Food Industry College. (3), 6-9 (1997)

4. Y.G.Shi, Z.H. Yang, B.Y.Sun, Journal of the Chinese Cereals and Oils Association. 20(4), 65-66, 76 (2005)

5. C. Li, B.F. Chai, A.H. Liang, M.B. Wang, Chin J Appl Environ Biol. 12 (1), 125-127 (2006)

6. W. Wang, L.P. Yin, Q. Chen, Journal of Shanghai University (Natural Science Edition). 13 (6), 746-750 (2007)

7. D.H.Jiang, B.F. Yang, M.J.Cai, D.N.Huang, X.H. Wei, Acta Agriculturae Zhejiangensis.,19 (3),174-178(2007)

8. Y. Liu, H.Y. Yao, Q. Wang, Journal of East China University of Science and Technology (Natural Science Edition). 33(2), 591-595(2007)

9. W. Wang, L.P.Yin, X.J.Liu, Q.Chen, Acta Botanica Boreali-Occidentalia Sinica.27 (1), 21-27(2007)

10. H. Ao, S.Q.Huang, J.X.Chen, Q.X. Zeng, Chin Med Biotechnol. 4 (5),359-363 (2009)

11. Y.J.Zheng, Y.Li, S.L.Zhao, H.Chen, W.J.Chen, Chinese Journal of Tropical Crops.30 (7), 1035-1038 (2009)

12. Q.P. Wen, C. Li, D.P. Xu, Q.Y. Cai, B. Pu, China Oils and Fats. 44(6), 50-55(2019)

13. J.L.Yang, H.M. Yang, L.R. Wu, J.M.Carney, C.H.Light, W. Cao, Y.H. Pan, Journal of Bamboo Research.38 (1), 1-8 (2019)

14. X.L. Feng, C.Q. Huang, Y.C. Xu, J.Y. Shen, W.T. Xie, Y.F. Yang, S.D. He, Farm Products Processing. (9), 30-34(2019)
15. F.J. Jiang, S.Y. Zhai, Y.F. Dai, J.X. Du, H. Wu, J.Q. Ma, T.T. Ma, S. Ma, J.F. Lu, Science and Technology of Food Industry.37(23), 239-242 (2016)

16. Y.Zhang, L. Zhang, H.Q. Zhang, C.B. Ding, Y.H. Zhou, Journal of Sichuan Agricultural University. 24(3), 256-262 (2006)

17. L.P. Xu, Y.N. Wang, H.L.Ma, Journal of the Chinese Cereals and Oils Association.14(5), 40-42 (1999)

18. H. He, X.G. Wang, L.Kong, Q.Z.Gu, Food Science. 25 (3), 184-187(2004)

19. H.L. Liu, J. Liu, P.T. Ding, Journal of Shenyang Pharmaceutical University.30(5), 403-408(2013)

20. H. Huang, X.Y. Li, J.W. Wang, W.H.Wu, R.H.Guo, Q.M.Yu, C.Y.Zhang, Food Science. 40(19), 318-325(2019)

21. Z.H. Chen, X.L. Gong, C. Cai, L.J. Zhang, Tianjin Pharmacy. 17(4), 1-2(2005)

22. M. M. Bradford, Anal Biochem. (72) ,248- 254 (1976)

23. X.Y.Liu, L.J. Yin, E.N. Yang, Journal of the Chinese Cereals and Oils Association. 11 (2), 23-27(1996)

24. Q. Ma, S.Y. Wang, L.L. Jiang, L.Z. Liu, Journal of Wuhan Polytechnic University. 28 (2), 5-10(2009)

25. J.H. Wang,X.M.Zhan, S. Yan, Journal of Anhui Agri. Sci.. 37 (34), 17080 - 17081, 17084(2009)

26. Z.H. Xu, H.T. Gao, Y.N. Ding, L.J. Wang, Q. Shen, Science and Technology of Food Industry.34(16), 276-279(2013)

27. Z.R. Deng, J.J. Sun, W.J. Zhang, Q. Chen, Journal of Shanghai University (Natural Science Edition).18(4), 430-434(2012) 